\title{
Assessment of a method for dental age assessment in panoramic radiographs and its relationship with the chronological age
}

\author{
Estudo de um método de avaliação da idade dentária em radiografias panorâmicas e sua \\ relação com a idade cronológica
}

\section{Lawrenne Ide KOHATSU \\ Jefferson Luis Oshiro TANAKA}

DDS, MSc, Doctoral graduate student, São José dos Campos Dental School - UNESP - São Paulo State University São José dos Campos - SP - Brazil

\section{Luiz Cesar de MORAES \\ Edmundo MEDICI FILHO}

Titular professor, Discipline of Oral Radiology, São José dos Campos Dental School - UNESP - São Paulo

State University - São José dos Campos - SP - Brazil.

\section{Mari Eli Leonelli de MORAES}

Assistant professor, Discipline of Oral Radiology, São José dos Campos Dental School - UNESP - São Paulo State University - São José dos Campos - SP - Brazil.

\section{Julio Cezar de Melo CASTILHO}

Associate professor, Discipline of Oral Radiology, São José dos Campos Dental School - UNESP - São Paulo State University - São José dos Campos - SP - Brazil

\begin{abstract}
Our purpose on the present paper was to verify the reproducibility, the variability and the reliability of the analysis of the dental age (DA) and to assess its relationship with the chronological age (CA). Fifty-three panoramic radiographs from 32 female and 21 male Brazilian children, with ages ranging between 120 and 131 months were submitted to the assessment of their DA according to the general ${ }^{14}$ and the sex-adjusted ${ }^{15}$ Standards for the Chronology of Dental Mineralization by four examiners. A high intra-observer and inter-observer reproducibility was found for both sexes. The DA obtained with the general standard was lower than the CA for male and female individuals. With the sex-adjusted standard, we observed that the female individuals tend to have the DA lower than the CA. However, when the values for the CA were subtracted from the values for the DA obtained with the adjusted table, only $13.09 \%$ of male individuals and $7.03 \%$ of female individuals had the DA out of the acceptable limit of \pm 12 months. When the CA values were subtracted from the DA values obtained with the general standard, $4.76 \%$ of male individuals and $12.5 \%$ of female individuals were above or below the acceptable limit of \pm 12 months. Although the results for the differences between the DA and the CA of some examiners were statistically significant, these differences are clinically irrelevant. The dentists do not need previous experience with the method, since it is based on comparisons of the radiographic images of the teeth with standards of mineralization stages. Based on the results, we concluded that the method is highly reproducible both for the comparisons of the results of one examiner and for the comparison of the results of a group of examiners. As expected, it is applicable to the Brazilian population. The Dental Professionals do not need previous experience with the method, since it is based on the comparison of the radiographic images of the teeth with the stages of dental mineralization.
\end{abstract}

\section{UNITERMS}

Radiography, panoramic; Age determination by teeth. 


\section{INTRODUCTION}

Children with the same chronological age are frequently in different stages of biological development. Therefore, the use of chronological age as a biological maturity indicator is not recomended ${ }^{1,7,13}$. Hence, other parameters for the assessment of biological maturity like the dental age, have been sugested ${ }^{1}$.

The knowledge of the mineralization stages of permanent teeth has many applications in Dentistry. For example, in Forensics, the chronological age of children without birth record can be estimated by means of the assessment of their dental age. This is possible because the mineralization of dental tissues is little affected by the endocrine and nutritional alterations ${ }^{5}$. In Orthodontics, data about the growth and development of the children is widely employed during the diagnosis and treatment plan ${ }^{16}$.

In general, the events that characterize the human growth and development occur in a fairly uniform sequence for all the individuals. However, the chronology of these events are usually influenced by factors such as genetical ${ }^{4,9,11,12,18}$, climatic ${ }^{8,11,12}$, hormonal ${ }^{9}$, sex $^{8}$, biotype ${ }^{8}$, environment ${ }^{4,9,18}$ and nutrition ${ }^{8,9,11,12}$, which might explain the differences found for the growth standards from other populations compared to the Brazilians ${ }^{11,12}$. Therefore, specific standards for each ethnical group should be developed to compensate for these variations ${ }^{6}$.

Nicodemo, et al. ${ }^{14}$ (1974) studied a sample of 478 Caucasian Brazilians, with 0 to 25 years of age. The authors verified that the mineralization standards available in the literature are not applicable to our population. They created a new standard for the chronology of mineralization for Brazilians' permanent teeth. These standards rank each tooth in one of the eight stages according to their stage of mineralization.

Using mineralization standards for the local population is primordial for accurate diagnosis of the dental age. Thus, the aim of the present paper is to assess the reproducibility, the variability, the reliability and the relationship of the Standards for the Chronology of Dental Mineralization proposed by Nicodemo, et al. ${ }^{14}$ (1974) e Nicodemo, et al..$^{15}$ (1992) with the chronological age using panoramic radiographs.

\section{Material AND METHOdS}

The sample was comprised by 53 panoramic radiographs of Caucasian Brazilian individuals (21 males and 32 females), with ages between 120 and
131 months. The reason for choosing this age group was that such individuals have a high number of teeth in mineralization process.

The radiographs were digitized on a flatbed scanner with transparency unit (HP Scanjet 4c/T - Hewlett Packard Company - Houston - Texas - USA). Only the region of interest (ROI) (lower teeth) was selected for digitalization. Any identification of the patient was suppressed from the ROI to avoid bias on the analysis of the dental ages. For the analysis of the examiners a Powerpoint slideshow presentation was created with the digitized images. The dental ages (DA) of each image was determined by four examiners according to the Standards for the Chronology of Tooth Mineralization proposed by Nicodemo, et al. ${ }^{14}$ (1974) and according to the Standards for the Chronology of Tooth Mineralization adjusted for each sex proposed by Nicodemo, et al. ${ }^{15}$ (1992). Only the cuspids, first bicuspids, second bicuspids and second molars of both sides were evaluated. Instructions about how to use the methods were given to the examiners before the task were assigned.

The examiners had to rank each tooth in one of the eight stages of tooth mineralization: 1) first evidence of mineralization, 2) $1 / 3$ of mineralized crow, 3) $2 / 3$ of mineralized crown, 4) mineralization of crown completed, 5) onset of root mineralization, 6) 1/3 of mineralized root, 7) $2 / 3$ of mineralized tooth and 8) apex closure. The same standard was followed for uni and multi-rooted teeth.

For each sex, each examiner generated two sets of data, one with the general and another with the sex-adjusted standard.

The DA of an individual was determined as the mean for the dental ages of each tooth. Two DA were calculated in moths with the dataset of one examiner: one with the General Standard for the Chronology of Tooth Mineralization ${ }^{14}$ (1974) and another with the Sex-adjusted Standard for the Chronology of Tooth Mineralization ${ }^{15}$ (1992). The same procedure was followed with the data provided by the other examiners.

For the intra-examiner analysis, the dental ages of the sample was recalculated after a two-week interval and analyzed with a linear regression statistics.

The intra-examiner reproducibility was assessed by comparing the first and the second readings of each method with the Pearson correlation test. If $r>0.80$, the mean for the first and the second readings would be calculated for the other statistical tests. The interexaminer concordance was assessed with the multiple 
linear regression analysis. A good concordance would be achieved if $r>0.80$.

The mean DA obtained by each examiner was compared with the main CA with the Student's $t$-test to verify if the null hypothesis "The dental age is not statistically different from the chronological age" is true.

The percentage of individuals with DA above or below the clinically acceptable limit of \pm 12 months was determined by calculating the difference of the DA found by each examiner using the general standards and the CA. The amount individuals whose difference between the DA and the CA was more than +12 months or less than -12 months were counted. The same procedure was followed for the results of the other examiners on both sex groups.

\section{Results}

Table 1 shows the Pearson $r$-values for the intraexaminer reproducibility using the general standards and the sex-adjusted standards.

Since $r>0.80$ for the first and the second readings of all the examiners, the mean for the first and the second readings of each examniner was calculated for the other statistical analysis.

Table 2 shows the $r$-values for the linear regression analysis of the inter-examiner reproducibility using the general standard and the sex-adjusted standard.

Table 3 shows the $n$, the mean and the standarddeviation for the DA obtained by each examiner, the mean and standard-deviation of the CA and the $p$-values for the comparisons between the mean for the DA determined by each examiner and the chronological age for the female individuals.

Table 4 shows the $\mathrm{n}$, the mean and the standarddeviation for the DA obtained by each examiner, the mean and stadard-deviation of the CA and the $p$-values for the comparisons between the mean for the DA determined by each examiner and the chronological age for the male individuals.

Table 5 shows the mean, the minimum and the maximum for the differences of the CA and the DA obtained by each examiner with the general table and the sex-ajusted standard, as well as the amount and percentage of individuals with DA above or below the clinically acceptable limit of \pm 12 months in relation to the $\mathrm{CA}$ for the female individuals.

Table 6 shows the mean, the minimum and the maximum for the differences between the $\mathrm{CA}$ and the DA obtained by each examiner with the general table and the sex-ajusted standard, as well as the amount and percentage of individuals with DA above or below the clinically acceptable limit of \pm 12 months in relation to the CA for the male individuals.

\section{Discussion}

The Pearson correlation test demonstrated a good intra-examiner concordance both with the general table and the adjusted table ( $r>0.80)$ (Table 1). The inter-examiner test also demonstrated a good correlation among the results of all the examiners $(r>0.80)$ (Table 2). With these data it is possible to state that the results from the comparison of one same examiner as well as from the comparison among examiners are closely related, which proves the easiness of the methods.

We observed that, in general, the DA for the female individuals were, on average, lower than their CA using both the general and the adjusted standards for tooth mineralization, except for the results of examiner 4, where DA was found to be, on average, higher than CA (Table 3). However, statistically significant differences of CA and DA were found to be statistically significant only for the results of examiners 2 and 3

TABLE 1 - Correlation coefficients for the intra-examiner analysis.

\begin{tabular}{|c|c|c|c|c|c|c|c|c|}
\hline & \multicolumn{2}{|c|}{ Exam. 1} & \multicolumn{2}{|c|}{ Exam. 2} & \multicolumn{2}{|c|}{ Exam. 3} & \multicolumn{2}{|c|}{ Exam. 4} \\
\hline & $A^{*}$ & $B^{\star *}$ & $A^{*}$ & $B^{\star \star}$ & $A^{*}$ & $B^{\star *}$ & $A^{*}$ & $\mathrm{~B}^{\star *}$ \\
\hline Females & 0.93 & 0.93 & 0.90 & 0.91 & 0.84 & 0.84 & 0.93 & 0.92 \\
\hline Males & 0.82 & 0.83 & 0.94 & 0.92 & 0.83 & 0.81 & 0.92 & 0.92 \\
\hline
\end{tabular}


Matuda FS, Pagani C, Miranda CB, Crema AAS, Brentel AS, Carvalho YR

ASSESSMENT OF A METHOD FOR DENTAL AGE ASSESSMENT IN PANORAMIC RADIOGRAPHS AND ITS RELATIONSHIP WITH THE CHRONOLOGICAL AGE

TABLE 2 - Correlation coefficients for the inter-examiner analysis.

\begin{tabular}{lcc}
\hline & Females & Males \\
\hline General table & 0.92 & 0.94 \\
Sex-adjusted table & 0.93 & 0.95 \\
\hline
\end{tabular}

when using the general standards. When the DA was calculated according to the adjusted standards, statistically significant differences were found for examiners 2 and 4 (Table 3).

Although statistically significant differences have been found for $\mathrm{CA}$ and $\mathrm{DA}$, some authors state that differences up to \pm 12 months for CA and DA are considered clinically acceptable. According to our results, we observed that, on average, the differences between $\mathrm{CA}$ and DA of female individuals have not exceeded \pm 12 months using both the general and the adjusted standards (Tables 3 and 4). However, we verified that

TABLE 3 - $n$, mean and standard-deviation (SD) in months for the DA determined by each examiner with the general table and the sex-adjusted table; mean and standard-deviation for the CA; $p$-values for the comparisons between the CA and the DA found by each examiner (female individuals).

\begin{tabular}{lllllll}
\hline \multicolumn{7}{c}{ Female individuals } \\
\hline Examiner & $\mathbf{n}$ & $\begin{array}{l}\text { Mean } \pm \text { SD } \\
\text { General } \\
\text { standards }\end{array}$ & $\begin{array}{l}\text { Sex-adjusted } \\
\text { standards }\end{array}$ & CA & $\begin{array}{l}\text { P-value } \\
\text { General } \\
\text { standards }\end{array}$ & $\begin{array}{l}\text { Sex-adjusted } \\
\text { standards }\end{array}$ \\
\hline 1 & 32 & $120.96 \pm 6.83$ & $119.88 \pm 6.01$ & $124.16 \pm 3.65$ & 0.02 & 0.00 \\
2 & 32 & $123.21 \pm 9.75$ & $121.17 \pm 7.45$ & $124.16 \pm 3.65$ & 0.60 & 0.05 \\
3 & 32 & $121.97 \pm 5.00$ & $120.91 \pm 4.31$ & $124.16 \pm 3.65$ & 0.50 & 0.00 \\
4 & 32 & $127.54 \pm 8.01$ & $124.77 \pm 5.56$ & $124.16 \pm 3.65$ & 0.03 & 0.60 \\
\hline
\end{tabular}

TABLE 4 - $n$, mean and standard-deviation (SD) in months for the DA determined by each examiner with the general table and the sex-adjusted table; mean and standard-deviation for the CA; $p$-values for the comparisons between the CA and the DA found by each examiner (male individuals).

\begin{tabular}{|c|c|c|c|c|c|c|}
\hline \multicolumn{7}{|c|}{ Male individuals } \\
\hline \multirow[t]{2}{*}{ Examiner } & \multirow[t]{2}{*}{$n$} & \multicolumn{3}{|l|}{ Mean \pm SD } & \multicolumn{2}{|l|}{$P$-value } \\
\hline & & $\begin{array}{l}\text { General } \\
\text { standards }\end{array}$ & $\begin{array}{l}\text { Sex-adjusted } \\
\text { standards }\end{array}$ & $\mathrm{CA}$ & General standards & $\begin{array}{l}\text { Sex-adjusted } \\
\text { standards }\end{array}$ \\
\hline 1 & 21 & $122.23 \pm 4.41$ & $127.06 \pm 4.79$ & $123.62 \pm 3.35$ & 0.26 & 0.01 \\
\hline 2 & 21 & $121.39 \pm 6.04$ & $126.09 \pm 6.40$ & $123.62 \pm 3.35$ & 0.15 & 0.13 \\
\hline 3 & 21 & $123.80 \pm 3.74$ & $128.27 \pm 4.44$ & $123.62 \pm 3.35$ & 0.87 & 0.00 \\
\hline 4 & 21 & $126.62 \pm 7.03$ & $131.77 \pm 7.24$ & $123.62 \pm 3.35$ & 0.09 & 0.00 \\
\hline
\end{tabular}


ASSESSMENT OF A METHOD FOR DENTAL AGE ASSESSMENT IN PANORAMIC RADIOGRAPHS AND ITS RELATIONSHIP WITH THE CHRONOLOGICAL AGE

on average smaller differences were obtained when the DA was calculated according to the general standards (0.739 months) than when using the adjusted standards for the females (2.471 months) (Table 5). On the other hand, the amount of individuals with differences of DA and CA exceeding the limit of 12 months was, on average, smaller than using the adjusted standards $(7.03 \%)$ than when using the general standards (12.5\%) (Table 5). Moreover, the number of individuals whose differences of DA and CA exceeded the limit of 12 months found by each examiner with the adjusted standards was more constant.

On the other hand, we observed a tendency of the male individuals to have, on average, the DA lower than the CA when the general standards were employed, except for examiners 3 and 4 . These differences were found to be statistically significant for all the examiners (Table 2). Conversely, when the adjusted standards were used, we observed a tendency of the DA to be, on average, higher than the CA. These differences were also statistically significant except for examiner 2 (Table 2).
Nevertheless, we observed that, on average, the differences between the DA and the CA were smaller with the general standards ( 0.111 months) in comparison to the differences found with the adjusted standards for male individuals (-4.677). Moreover, the amount of individuals whose DA was out of the \pm 12 months was greater when the adjusted standards were employed (13.09\%) in comparison to the general standards (4.76\%) (Table 6).

A thorough analysis of the results demonstrated that most of the individuals with DA found to be above or below the limit of \pm 12 months were due to individual and external reasons instead of problems with the adjustment of the standards to a certain population. This observation was drawn from the fact that only a few individuals with the DA above or below the acceptable limit were detected. Also, when such individual was detected by one observer, the results of at least one other examiner pointed the same, which proves the influence of external and individual factors on the delay or advance of dental age.

TABLE 5 - Mean, minimum and maximum for the differences in months of the CA and the DA; amount and percentage of individuals with DA out of the clinically acceptable limit of \pm 12 months (female individuals). Values obtained with the general and the sex adjusted table.

\begin{tabular}{|c|c|c|c|c|c|c|}
\hline \multicolumn{7}{|c|}{ FEMALE INDIVIDUALS } \\
\hline & & Exam. 1 & Exam. 2 & Exam. 3 & Exam. 4 & Mean \\
\hline \multirow{5}{*}{$\begin{array}{l}\frac{0}{0} \\
\frac{0}{\sigma} \\
\frac{\pi}{0} \\
\frac{0}{0} \\
\frac{1}{0} \\
0\end{array}$} & Means & 3.199 & 0.950 & 2.191 & -3.382 & 0.739 \\
\hline & Minimum & -7.225 & -21.150 & -6.625 & -23.200 & \\
\hline & Maximum & 24.713 & 26.575 & 22.163 & 13.700 & \\
\hline & $\begin{array}{l}\text { Individuals out of the } \\
\text { acceptable limit }\end{array}$ & 2 & 6 & 2 & 6 & 4 \\
\hline & $\begin{array}{l}\% \text { of individuals out of the } \\
\text { acceptable limit }\end{array}$ & 6.25 & 18.75 & 6.25 & 18.75 & $12.5 \%$ \\
\hline \multirow{5}{*}{ 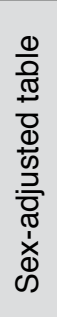 } & Means & 4.275 & 2.983 & 3.242 & -0.617 & 2.471 \\
\hline & Minimum & -4.725 & -12.775 & -4.600 & -11.600 & \\
\hline & Maximum & 23.544 & 25.275 & 21.331 & 13.875 & \\
\hline & $\begin{array}{l}\text { Individuals out of the } \\
\text { acceptable limit }\end{array}$ & 3 & 3 & 2 & 1 & 2.25 \\
\hline & $\begin{array}{l}\% \text { of individuals out of the } \\
\text { acceptable limit }\end{array}$ & 9.38 & 9.38 & 6.25 & 3.125 & $7.03 \%$ \\
\hline
\end{tabular}


ASSESSMENT OF A METHOD FOR DENTAL AGE ASSESSMENT IN PANORAMIC RADIOGRAPHS AND ITS RELATIONSHIP WITH THE CHRONOLOGICAL AGE

TABLE 6 - Mean, minimum and maximum for the differences in months of the CA and the DA; amount and percentage of individuals with DA out of the clinically acceptable limit of \pm 12 months (male individuals). Values obtained with the general and the sex adjusted table.

\begin{tabular}{|c|c|c|c|c|c|c|}
\hline \multicolumn{7}{|c|}{ MALE INDIVIDUALS } \\
\hline & & Exam. 1 & Exam. 2 & Exam. 3 & Exam. 4 & Média \\
\hline \multirow{5}{*}{ 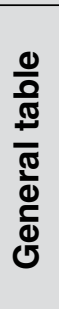 } & Mean & 1.387 & 2.233 & -0.180 & -2.999 & 0.111 \\
\hline & Minimum & -9.584 & -8.372 & -8.372 & -23.813 & \\
\hline & Maximum & 10.963 & 14.588 & 7.350 & 7.219 & \\
\hline & $\begin{array}{l}\text { Individuals out of the } \\
\text { acceptable limit }\end{array}$ & 0 & 1 & 0 & 3 & 1 \\
\hline & $\begin{array}{l}\% \text { of individuals out of the } \\
\text { acceptable limit }\end{array}$ & 0.0 & 4.8 & 0.0 & 14.3 & 4.76 \\
\hline \multirow{5}{*}{ 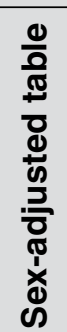 } & Mean & -3.439 & -2.471 & -4.649 & -8.149 & -4.677 \\
\hline & Minimum & -14.877 & -13.393 & -12.562 & -29.506 & \\
\hline & Maximum & 7.213 & 9.731 & 4.063 & 3.669 & \\
\hline & $\begin{array}{l}\text { Individuals out of the } \\
\text { acceptable limit }\end{array}$ & 2 & 3 & 2 & 4 & 2.75 \\
\hline & $\begin{array}{l}\text { \% of individuals out of the } \\
\text { acceptable limit }\end{array}$ & 9.5 & 14.3 & 9.5 & 19.0 & 13.09 \\
\hline
\end{tabular}

Our results support the applicability of the general and the sex-adjusted standards for the chronology of tooth mineralization proposed by Nicodemo, et al. ${ }^{14,15}$ (1974 and 1992) for the Brazilian population.

We also observed that the method is easy to use, since it is based on the comparisons of the radiographic images of the permanent teeth with the stages of mineralization proposed by Nicodemo, et al. ${ }^{14}$ (1974). Therefore, this method can be used by any dental professional without previous experience ${ }^{8}$.

\section{Conclusions}

- There is a high correlation for both intra-examiner and intra-examiner results of DA with either the general or the adjusted standards for the chronology of tooth mineralization proposed by Nicodemo, et al. ${ }^{14,15}(1974,1992)$, which proves the reliability of the method.

- On average the differences found between the DA and the CA didn't exceed the clinically acceptable limit of \pm 12 months using both the general and the sex-adjusted standards, although statistically significant differences between the DA and the CA have been detected for results of some examiners.

- The general standards provide, on average, closer DA in relation to the CA; however, only the amount of individuals out of the acceptable limit of \pm 12 months is greater when using the adjusted standards for male individuals.

- The data from the present study support the applicability of the General and the Sex-Adjusted Standards for the Chronology of Dental Mineralization proposed by Nicodemo et al. ${ }^{14,15}$ (1974, 1992) to the Brazilian population. 


\section{Resumo}

O objetivo deste estudo foi verificar a reprodutibilidade, variabilidade e fidelidade de um método de avaliação da Idade Dentária (ID) e analisar sua relação com a Idade Cronológica (IC). Foram utilizadas 53 radiografias panorâmicas, de crianças brasileiras, sendo 32 do sexo feminino e 21 do masculino, na faixa etária entre 120 a 131 meses. As avaliações foram realizadas por 4 examinadores, por meio da Tabela de Cronologia da Mineralização Dentária geral ${ }^{14}$ e a adaptada para os sexos ${ }^{15}$. Verificou-se uma alta reprodutibilidade intra-observador e inter-observadores, tanto para o sexo feminino quanto para o masculino. Verificou-se que a ID obtida com a tabela geral é menor do que a IC para os dois sexos. Já com a tabela ajustada, observou-se que no sexo feminino as ID tendem a ser menores do que a IC, enquanto que para os indivíduos do sexo masculino, as ID tendem a ser maiores do que a IC. Entretanto, quando se subtraiu a IC da ID obtidas com a tabela ajustada, apenas $13,09 \%$ dos indivíduos do sexo masculino e 7,03\% do feminino apresentavam ID fora da faixa de tolerância de \pm 12 meses. Quando os valores de IC foram subtraídos da ID com a tabela geral, $4,76 \%$ dos indivíduos do sexo masculino e 12,5\% dos indivíduos do sexo feminino estavam acima ou abaixo do limite aceitável dos \pm 12 meses. Baseado nos resultados, concluímos que o método é reprodutível tanto intra quanto inter-observadores. Apesar das diferenças entre IC e ID obtidas por alguns examinadores serem estatisticamente significantes, em termos práticos, esta diferença se torna relevante somente quando ultrapassa os \pm 12 meses. Portanto, tanto a tabela geral quanto a ajustada são aplicáveis à população brasileira. Os Cirurgiões-dentistas não necessitam de experiência prévia com o método, por ser baseado na comparação de imagens radiográficas dos dentes com os estágios de mineralização, o qual é de fácil emprego.

\section{UnITERMOS}

Radiografia panorâmica; Determinação da idade pelos dentes.

\section{References}

1. Benemann E, Sampaio R, Berthold T. Idade biológica: indicadores do surto de crescimento. Ortodontia Gaúcha. 1997;1(1):62-76.

2. Bolaños MV, Manrique MC, Bolaños MJ, Briones MT. Approaches to chronological age assessment based on dental calcification. Forensic Sci Int. 2000;110(2):97-106.

3. Carvalho AAF. Estimativa de valores médios de crescimento em criancas com idade cronológica variando de 84 a 131 meses. Rev Odontol UNESP. 1993;22(2):293-301.

4. Chaves AP, Ferreira RI, Araújo TM. Maturação esquelética nas raças branca e negra. Ortodontia Gaúcha. 1999;3(1):45-52.

5. Eid RMR, Simi R, Friggi MNP, Fisberg M. Assessment of dental maturity of Brazilian children aged 6 to 14 years using Demirjian's method. Internac. J Paediatric Dentist. 2002;12:423-8.

6. Farah CS, Booth DR, Knott SC. Dental maturity of children in Perth, Western Australia, and its application in forensic age estimation. J Clin Forensic Med. 1999;6:14-8.

7. Flores-Mir C, Maurício FR, Orellana MF, Major PW. Association between growth stunting with dental development and skeletal maturation stage. Angle Orthod. 2005;75(6):935-40.

8. Gonçalves ACS, Antunes JFL. Estimativa da idade em crianças baseada nos estágios de mineralização dos dentes permanentes, com finalidade odontolegal. Odontologia e Sociedade. 1999;1(1/2):55-62.

9. Gonçalves A, Usberti AC, Boscolo FN. Estudo dos estágios de desenvolvimento do primeiro molar permanente inferior e sua relação com a idade cronológica em crianças leucodermas da região de Piracicaba. Rev Odontol Univ São Paulo. 1994;8:275-80.

10. Medici Filho E. Cronologia da mineralização dos caninos, pré-molares e segundos molares permanentes, entre leucodermas brasileiros. Rev Fac Odont São José dos Campos. 1974;3(1):57-64.

11. Moraes LC. Cronologia da mineralização dos incisivos e primeiros molares permanentes entre leucodermas brasileiros da região sudeste. Rev Fac Odont São José dos Campos. 1974;3(1):65-71
12. Moraes LC, Medici Filho E, Castilho JCM, Leonelli ME. Idade óssea: considerações a respeito de sua estimativa. RGO. 1994;42:201-3.

13. Moraes MEL, Medici Filho E, Moraes LC. Surto de crescimento puberal. Relação entre mineralização dentária, idade cronológica, idade dentária e idade óssea - método radiográfico. Rev Odontol UNESP. 1998;27(1):111-29

14. Nicodemo RA, Moraes LC, Medici Filho E. Tabela cronológica da mineralização dos dentes permanentes entre brasileiros. Rev Fac Odont São José dos Campos. 1974;3(1):55-6.

15. Nicodemo RA, Moraes LC, Medici Filho E. Tabela cronológica da mineralização dos dentes permanentes sob o aspecto da diferença entre os sexos. Ortodontia. 1992;25(1):18-20.

16. Nolla CM. The development of the permanent teeth. J Dent Child. 1960;27:254-66.

17. Sahin Saglam AM, Gazilerli U. The relationship between dental and skeletal maturity. J Orofac Orthop. 2002;63(6):454-62.

18. Silva SRP, Nouer PRA, Garbui IU, Ramalho SA. Definição da época para início do tratamento ortodôntico. RGO. 2005;53(4):273-6.

19. Souza-Freitas JA, Tavano O, Álvares LC, Lopes ES. Aplicação odontolegal de algumas tabelas cronológicas da evolução dental. Estomat Cult. 1970;4(2):181-200.

Recebido em 29/04/07 Aprovado em 27/08/07

Corresponding to: Lawrenne Ide Kohatsu UNESP - FOSJC Av. Eng. Francisco José Longo, 777 - Jardim São Dimas 12.245-000 - São José dos Campos - SP e-mail: likohatsu@hotmail.com 